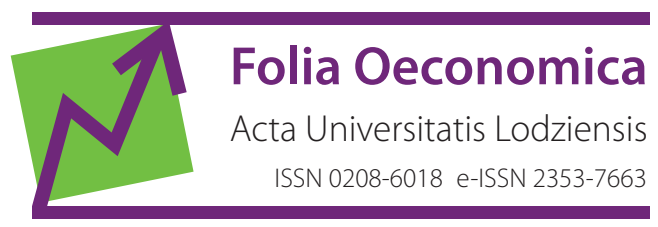

www.czasopisma.uni.lodz.pl/foe/

5(344) 2019

DOI: http://dx.doi.org/10.18778/0208-6018.344.09

\author{
Wiesław Tadeusz Wątroba \\ Uniwersytet Ekonomiczny we Wrocławiu, Wydział Nauk Ekonomicznych \\ Katedra Socjologii i Polityki Społecznej, wieslaw.watroba@ue.wroc.pl
}

\title{
Transgresywność systemów wartości pokoleń we współczesnym kapitalizmie ${ }^{1}$
}

Streszczenie: Artykuł stanowi próbę rewizji dotychczasowej percepcji kategorii pokolenia, sugerującej periodyzację i identyczność przedziałów czasowych przypisywanych kolejnym generacjom. Zawarta w nim analiza porównawcza została oparta na nowym ujęciu pokolenia, wyznaczanym przez procesy społeczne i psychologiczne determinowane wydarzeniami historycznymi i kontekstem ekonomicznym, stymulujące wspólną tożsamość i świadomość pokoleniową, nie zaś na podstawie zbliżonej daty urodzenia. Szczegółowym przedmiotem analizy są różnice, czy raczej transgresje, charakteryzujące najważniejsze wartości pokoleń rezydujących w obrębie tzw. późnego kapitalizmu, tj. jego obecnego ponowoczesnego etapu.

Słowa kluczowe: pokolenie, ciche pokolenie, baby boomers, pokolenie Jones, pokolenie X, echo boomers, milenialsi, pokolenie Y, pokolenie internetu

JEL: A13

1 Artykuł stanowi rewizję koncepcji kategorii pokolenia zawartej w monografii Transgresje międzypokoleniowe późnego kapitalizmu (Wątroba, 2017) oraz nawiązuje do złożonego do publikacji artykułu Trans-generational regime of late capitalism. Introducing a new sociology of generation (Wątroba, 2018). 


\section{Wprowadzenie}

Bardzo ważną determinantą świadomości i zachowań jednostek - oprócz tak oczywistych, jak rasa, płeć, wyznanie, przynależność etniczna, światopogląd, poglądy polityczne, wykształcenie, wiedza, doświadczenia życiowe czy status społeczno-ekonomiczny - jest ich przynależność pokoleniowa (Lancaster, Stillman, 2002: 13) czy raczej tożsamość pokoleniowa, tj. indywidualny wybór solidaryzowania się $\mathrm{z}$ osobami urodzonymi $\mathrm{w}$ określonym czasie, stanowiącymi określoną kohortę (Wątroba, 2017: 19).

Autentycznych, a nie metrykalnych członków pokolenia charakteryzują wspólne, wyraziste - odmienne od innych pokoleń - założenia dotyczące rzeczywistości społecznej, ukształtowane przez ich własne doświadczenia, specyficzny i unikalny zestaw wartości, postaw i zachowań implikujących ich reakcje na otoczenie, a w efekcie wyznaczających zmiany w różnych aspektach ich społecznej egzystencji. Pokolenie „charakteryzuje pewien stopień przewidywalności cech, wartości czy przekonań, jak i umiejętności, atrybutów, kompetencji, zainteresowań, oczekiwań i preferowanych wzorów zachowań, wyznaczający jego miejsce w porządku pokoleniowym" (Pendergast, 2010: 1; Wątroba, 2017: 31). Pokolenie zyskuje swoją wyrazistość nie tylko przez manifestację różnic w stosunku do innych pokoleń, ale również przez unikatowe cechy, własny system wartości i przekonania, przez odmienne - szczególnie w stosunku do poprzedniej generacji - poglądy i praktyki religijne i polityczne, przez nowe wzory konsumpcji, własną wizję rodziny czy - szerzej - przez wizję życia zbiorowego (Pendergast, 2010: 3). W konsekwencji różnice między pokoleniami znajdują swój wyraz behawioralny w rytuałach i ceremoniach, obrzędach przejścia, nacechowanych symbolizmem zróżnicowanym w zależności od kontekstu kulturowego (Eisenstadt, 2003: 31-32; Wątroba, 2017: 34), w decyzjach konsumenckich, formach spędzania czasu wolnego czy preferencjach w odbiorze kultury popularnej.

Nośnikiem powyższych odmienności kształtujących nową generację jest - cechująca każdą epokę w historii społecznej (wręcz ją konstytuująca) - dominująca grupa wiekowa, swego rodzaju awangarda, która wyznacza nadzieje, pragnienia i ambicje nie tylko swoich rówieśników, ale i innych współczesnych im jednostek. Akceptują one proponowaną przez nich wyrazistość pokoleniową, dążąc do przejęcia przewodnictwa w ich realizacji (Savage, 2008: 184; Wątroba, 2017: 19). Grupę tę stanowią tzw. transgresjoniści pokoleniowi (szerzej w: Wątroba, 2017: 264-270).

Transgresjonistów stanowiących awangardę pokoleniową kreuje historia - pojawiają się w okresie dynamicznych zmian społecznych, ekonomicznych i politycznych, stając się ich podmiotem, nośnikiem nowych idei, a niektórzy z nich przywódcami ruchów implementujących nowy porządek, za którymi podążają inni, głównie nieco młodsze od nich zbiorowości, ale również przedstawiciele 
starszych. Jednakże historia społeczna nie jest pisana jedynie permanentną zmianą. W generacyjnej historii społeczeństw zachodnich mamy czasami do czynienia ze zjawiskiem pokoleniowego interregnum, charakteryzującego się tym, że w rzeczywistości społecznej pojawia się pewna, niemała liczba osób, które nie utożsamiają się z żadną generacją (Wątroba, 2017: 50). Są to jednostki urodzone „na krawędzi” (cusp) między dwiema generacjami, które mogą odczuwać więzi z jedną bądź drugą generacją, ale najczęściej ich tożsamość wznosi się ponad tożsamość dwóch pokoleń (Lancaster, Stillman, 2002: 32).

Idea pokoleniowego interregnum $\mathrm{w}$ analizie historycznej wyklucza pogląd klasyka teorii pokoleń, francuskiego socjologa Françoise Mentre’a. Twierdzi on, że społeczną historię ludzkości należy dzielić na okresy około dwudziestu-trzydziestu lat, czyli czas trwania odwiecznej „walki synów przeciw ojcom” (Mentré, 1920, za: Savage, 2008: 184; Wątroba, 2017: 19), która odpowiada kolejnym - bardziej lub mniej - wyrazistym generacjom. Ta powielana przez wielu badaczy koncepcja ma wątpliwą - wręcz szkodliwą - wartość dla socjologicznej interpretacji kategorii pokolenia. Jest ona przydatna jedynie w analizie rodziny, rodu, klanu czy plemienia. Wychodzi naprzeciw oświeceniowym mrzonkom uporządkowania rzeczywistości, usunięcia z niej wieloznaczności, jednak w przypadku konstrukcji intelektualnej, jaką jest generacja, jest wysoce nieadekwatna i nierealna, gdyż wszelkie próby tak ścisłej periodyzacji (opartej na równych czasowo okresach) są utopijne, radykalnie deterministyczne, niepoparte rzetelnymi badaniami empirycznymi, ocierając się o absurd (Howe, Strauss, 1991). Na dodatek koncepcja ta utrwala pogląd, że w badaniach generacji należy wyznaczać jednolite ramy czasowe dla kolejnych pokoleń, pomijając historyczny kontekst ich społecznej egzystencji. Tego typu periodyzacja może być stosowana $\mathrm{w}$ analizie statystycznej jedynie do kohort, czyli osób urodzonych w badanych przedziałach czasowych, ale nie w odniesieniu do generacji w sensie socjologicznym. Generacji w ujęciu socjologicznym nie stanowią osoby urodzone w określonym czasie, gdyż, jak słusznie zauważył Karl Mannheim (szerzej w: Mannheim, 1952), fakt przyjścia na świat $\mathrm{w}$ danym przedziale czasu nie wyznacza identycznej percepcji rzeczywistości. Według niego kształtowanie się tożsamości i świadomości pokoleniowej stymulują procesy społeczne i psychologiczne, a nie urodzenie się w danym okresie. Świadomości pokoleniowej nie wyznacza data urodzenia, lecz „doświadczanie rzeczywistości we wspólnym, społecznym i politycznym kontekście, zaś przynależność do określonej generacji jest kombinacją stanu umysłu i zbliżonego wieku" (za: Morgan, Kunkel, 2011: 10; szerzej w: Wątroba, 2017: 22). Świadomość ta jest kształtowana przede wszystkim przez wydarzenia zachodzące w otoczeniu jednostki, w okresie jej dorastania i we wczesnej dorosłości, gdyż to właśnie ,wczesne doznania - jak pisał Mannheim - przejawiają tendencję do zespalania się w jeden, naturalny obraz świata" (za: Gillon, 2004: 3; szerzej w: Wątroba, 2017: 23). 
Pionierami nowego pokolenia są wcześniej wspomniani transgresjoniści, a sama generacja konstytuuje się dzięki transgresjom międzypokoleniowym, tj. procesom skutkującym wspólną tożsamością, relatywnie trwałą w późniejszym okresie, wyrażaną choćby w podzielaniu podobnych wzorców zachowań w określonych sytuacjach, na kolejnych etapach życia (za: Gillon, 2004: 3; szerzej w: Wątroba, 2017: 23). Generację - w sensie socjologicznym - stanowią jednostki o podobnym doświadczaniu wydarzeń historycznych, ich grupowa interpretacja tych wydarzeń stanowi zaś klucz do konstruowania nowego pokolenia (Erickson, 2008: 5). Generacje są tworzone przez historię, nie rodzą się tak po prostu (Owram, 1997: xiii). Różnią się formą adaptacji społecznej historii, wyznaczając własne, społeczne i kulturowe miejsce w rzeczywistości społecznej - „kolektywnie odczuwając nostalgię za wartościami swojej młodości, a także poszukując swojego ostatecznego przeznaczenia" (Strauss, Howe, Markiewicz, 2006: 20). Każdą generację charakteryzuje unikalna osobowość rówieśnicza, dzięki której jej przedstawiciele przeżywają wydarzenia po swojemu, stymulując „,przewrotowo-masową zmianę jakościową, która sprzyja poczuciu odrębności pokoleniowej" (Świda-Ziemba, 2005: 15). Jednakże odrębność ta nie jest zawłaszczana tylko przez rówieśników, jest także propagowana wśród starszych i młodszych kohort, a „różnice pokoleniowe istnieją po prostu dlatego, że ludzie wierzą w ich istnienie, że grupy pokoleniowe stają się samoutrwalającą się strukturą" (Benckendorff, Moscardo, Pendergast, 2010: x). Wiara ta jest wzmacniana przez tzw. „legendy pokoleniowe, czyli zmitologizowane opowieści o losach pokolenia, tworzone na ogół ex post i podtrzymujące pokoleniową tożsamość" (Garewicz, 1983 za: Fatyga, 2005: 196). Dokonując - dość daleko idącego, wymuszonego ramami artykułu - uproszczenia, za podstawowe determinanty kategorii pokolenia należy uznać:

1) wysoki stopień jego odmienności od pokolenia go poprzedzającego;

2) wyrazistość wyznaczającą jego znaczenie i wpływ na rzeczywistość społeczną oraz na zdolność dostosowania instytucji społecznych do jego przekonań i wartości;

3) wspólne doświadczanie wydarzeń historycznych, ich zbiorową interpretację - tożsamość pokoleniowa jednostki nie jest kształtowana przez historię, lecz przez adaptację społecznej historii zbiorowości, głównie w okresie dorastania; 4) specyficzny i unikalny zestaw wartości, postaw i zachowań, implikujący reakcje na zmiany w różnych aspektach egzystencji jego przedstawicieli oraz możliwość kreacji nowych form ich otoczenia społecznego.

Przy tak przyjętej konceptualizacji kategorii pokolenie dla potrzeb artykułu dokonano skrótowej, podyktowanej jego ograniczeniami, analizy następujących generacji (w nawiasach wskazane są roczniki - właściwych tym generacjom - wzmiankowanych wcześniej transgresjonistów, tj. reprezentantów awangardy każdej z generacji, ukazujących w najbardziej wyrazisty sposób jej cechy konstytutywne): 
1) najwspanialsze pokolenie (1920-1922),

2) ciche pokolenie (1936-1939),

3) złoci baby boomers (1944-1949),

4) pokolenie Jones (1957-1959),

5) pokolenie X (1967-1969),

6) pokolenie echo boomers (1981-1983),

7) milenialsi (millennials) czy raczej pokolenie internetu (1994-1996).

Strukturę artykułu oparto na posiadającej ciągle szerokie grono zwolenników konwencji grupującej najwspanialsze pokolenie i ciche pokolenie w tzw. tradycjonalistów, a złotych baby boomers i pokolenie Jones w opartą na kryteriach demograficznych kategorię baby boomers. W obu przypadkach wskazano różnice między tymi pokoleniami.

\section{Najwspanialsze pokolenie i ciche pokolenie}

System wartości obu pokoleń opierał się na niekwestionowanej - ich zdaniem - tradycji. Stąd też często określa się ich jako tradycjonalistów. Na takie określenie zasłużyli sobie przede wszystkim dochowaniem czy wręcz utrwaleniem tych wartości w skrajnie trudnych warunkach wojny i odbudowy zachodniego świata po jej zakończeniu.

Od najmłodszych lat historia ich nie oszczędzała - ich dzieciństwo przypadło na czas kryzysu ekonomicznego, a w wiek dorosły wkraczali w trakcie wojny. Stąd też charakteryzowało ich zdyscyplinowanie, osobista odpowiedzialność, obowiązkowość, honor, wiara w lepszą przyszłość, poświęcenie dla innych, szacunek dla instytucji społecznych oraz oddanie - jak sądzili - charyzmatycznym przywódcom. To oni en masse walczyli na frontach II wojny światowej, a po jej zakończeniu ruszyli do szkół i na uczelnie, jednocześnie pracując i ucząc się oraz zakładając rodziny, na co wcześniej nie mogli sobie pozwolić. Z oddziałów militarnych przeistoczyli się w nowy rodzaj armii, która wkraczała w „obszary przemysłu, nauki, sztuki, polityki publicznej, we wszystkie domeny [...] życia, niosąc ze sobą tę samą pasję i dyscyplinę, która towarzyszyła im w czasie wojny" (Brokaw, 2001: xix-xxi), „stając się kluczową siłą wyzwań i zamierzeń na skalę, jakiej dotąd świat nie był świadkiem" (Brokaw, 2001: 11). Nie liczyli na uznanie czy hołd, a u kresu swoich dni - podsumowując obiektywne sukcesy - ciągle przypominali o tych, co oddali życie za lepszy świat, który pragnęli zapewnić swoim dzieciom (Wątroba, 2012: 65-66; 2017: 53).

System wartości tradycjonalistów opierał się w dużej mierze na wartościach religijnych i etnicznych - czerpali radość ze wspólnych posiłków i zgromadzeń rodzinnych oraz ze spotkań społeczności religijnych. Lojalność i umiejętność pracy zespołowej znalazła swoje odzwierciedlenie w relacjach z przełożonymi i współ- 
pracownikami, w zdolności do wyrzeczeń i poświęcenia dla zbiorowości oraz w gotowości do odroczenia gratyfikacji zawsze, gdy miałoby to przynieść korzyść innym. Wartości materialne miały dla nich mniejsze niż dla młodszych pokoleń znaczenie, chociaż i oni stali się beneficjentami progresu ekonomicznego i cywilizacyjnego w drugiej połowie XX wieku (Wątroba, 2017: 53).

O ile stosunek do tradycji stanowił kluczowy element integrujący najwspanialsze pokolenie i ciche pokolenie, o tyle ich doświadczenia życiowe były odmienne. Ci drudzy nie zdążyli - z nielicznymi wyjątkami - wziąć udziału w wojnie, a w procesie odbudowy świata, choćby ze względów demograficznych, nie stanowili głównej siły. Przez całe życie musieli godzić się z rolą kohorty wciśniętej przez historię między samowystarczalne i asertywne najwspanialsze pokolenie a krnąbrnych i samorealizujących się baby boomers. Dlatego też wybrali pragmatyzm jako zasadniczą wartość, a jednocześnie jako strategię przetrwania. Ów pragmatyzm nakazywał im opowiedzieć się po stronie starszej generacji, przyjmując jej system wartości, licząc na schedę po niej, gdy wycofa się z aktywnego życia, oraz na beneficja powojennego boomu gospodarczego. Jednak ich aspiracje nie zostały poparte wypracowaniem własnej opowieści, która byłaby ciekawsza niż epopeja o najwspanialszym pokoleniu (Starr, 2009: 353) i zostały „zmiecione” przez demograficzną lawinę boomersów. Początkowo próbowali wcielić się w rolę mediatorów między tymi, jakże wyrazistymi kohortami, ale nikt nie chciał ich słuchać. Jedynie garstka z nich, jakby przewidując bieg nadchodzących zdarzeń, zaczęła kontestować tradycję, stając się inicjatorami i przywódcami duchowymi rewolty kulturowej, której podmiotem byli w istocie boomersi. Trudno jednak tych - jak ich określił Elwood Carlson - nielicznych szczęśliwców (Lucky Few) (Carlson, 2008: 11-12) uznać za reprezentantów cichego pokolenia. Byli oni raczej awangardą nowego pokolenia, mimo iż demograficznie należeli do poprzedniego. Większość ich rówieśników, po cichu podzielała tradycyjne wartości, a jednocześnie, niezbyt glośno opowiadała się za radykalnymi zmianami kulturowymi (Wątroba, 2017: 59), doskonale czując się w roli koncyliacyjnego pomostu między najwspanialszym pokoleniem a boomersami, prowadząc tych drugich - niczym troskliwi pasterze w duchu tradycyjnych wartości tych pierwszych - przez dzieciństwo i okres dorastania, a później z rzadka buntując się przeciwko wizji społecznego świata narzuconej przez swoich młodszych braci i siostry (Starr, 2009: 353; Wątroba, 2017: 56-57).

\section{Złoci baby boomers i pokolenie Jones}

Kluczowe dla modyfikacji systemu wartości najstarszego, ciągle aktywnego zawodowo pokolenia było upowszechnienie szkolnictwa ponadpodstawowego oraz gwałtowny, w wymiarze ilościowym, rozwój szkolnictwa wyższego po II woj- 
nie światowej. Szczególnie dzięki edukacji uniwersyteckiej boomersi dystansowali się, zarówno fizycznie (wygląd zewnętrzny, sprawność fizyczna, hierarchia potrzeb biologicznych), jak i emocjonalnie oraz kulturowo od starszych pokoleń, a w szczególności od swoich rodziców (Krauss Whitbourne, Willis, 2006: 250). Nie zamierzali wyrosnąć na ich podobieństwo, kontestując tradycyjne wartości, czerpiąc jednak korzyści z realizacji - przez starsze generacje - planu stworzenia lepszego świata, bez wojen, cechującego się dobrobytem ekonomicznym, którego beneficjentami staną się niemal wszyscy członkowie społeczeństwa.

Lata sześćdziesiąte, tj. dekada dorastania złotych boomersów, ostatecznie pozbawiły starsze generacje złudzeń o kultywowaniu tradycji w warunkach ekonomicznej prosperity. Mimo dobrych intencji to starsze pokolenia przyczyniły się w dużej mierze do drastycznej zmiany społecznych realiów kapitalistycznego świata, gdyż od najmłodszych lat stymulowały u boomersów przekonanie, że są szczególną generacją, że są najważniejsi, mądrzejsi, że należy się im pozycja podmiotów, a jednocześnie beneficjentów dynamicznego rozwoju powojennego świata. Trudno się zatem dziwić, że boomersi nie byli skłonni do akceptowania społecznego i politycznego obrazu świata urządzonego przez poprzednie pokolenia. Opuszczając mury szkół średnich, co najczęściej wiązało się z opuszczeniem domów rodzinnych, niemal w jednej chwili przeistaczali się z grzecznych dzieci - za jakie dotąd uchodzili - w kontestatorów dotychczasowego porządku, w tym, niestety, także rodziny - największej wartości dla wielu tradycjonalistów. Spektakularnym tego przykładem był wzrost liczby rozwodów i ponownie zawieranych małżeństw (szerzej w: Wątroba, 2017: 98-99).

Boomersi kontestowali także takie wartości społeczeństwa industrialnego jak kompetencje kulturowe, protestancki etos pracy, ascetyczna wizja sukcesu zawodowego i spełnienia w życiu osobistym. Zrelatywizowali również systemy hierarchii i autorytety charakteryzujące to społeczeństwo. Permisywizm gloryfikowany przez rewoltę lat sześćdziesiątych - poparty tolerancją dla niższych standardów - preferowany przez dorastających boomersów, dla których nowy porządek był wielce atrakcyjny, doprowadził do tego, że wysokie standardy społeczeństwa merytokratycznego przestały stanowić wartość same w sobie dla tego jakże ekspansywnego pokolenia (Daniels, 2006: 205-206; Wątroba, 2017: 104). Jednocześnie rewolta pokazała, iż baby boomers bardzo wysoko cenią wszelkie działania zbiorowe, co mogło być efektem ich dużej liczebności, wskutek której niemal wszystko, co robili, odbywało się zbiorowo (Twenge, 2006: 48; Wątroba, 2017: 104). Mimo iż uchodzą za indywidualistów, egocentryków, a wręcz zarzuca się im narcyzm, do dzisiaj czują się doskonale we wszelkich działaniach grupowych, nawet odindywidualizowali starość, którą dotąd zazwyczaj cechowała samotność.

Boomersom udzielił się klimat liberalizujących się uniwersytetów. Opowiadali się za powszechnym uznaniem wolności i równych praw dla wszystkich jednostek, za emancypacją grup społecznych dotąd pozbawionych dostępu do pełni 
praw. Podążając tropem nieco starszych swoich ideowych przywódców, stawali na czele ruchów obywatelskich na rzecz równości płci, rasy, wyznania, osób o odmiennych preferencjach seksualnych, niepełnosprawnych, a także na rzecz uszanowania prywatności jednostki. Dorastając w warunkach nienotowanego dotąd postępu cywilizacyjnego i egalitaryzacji jego dobrodziejstw, opartego na szybkim wzroście ekonomicznym, wśród wysokich oczekiwań związanych z przyszłością, pragnęli zmieniać otaczającą ich rzeczywistość czy wręcz cały świat na lepszy niż ten, który pozostawili im dziadkowie i rodzice (Cochran, Rothschadl, Rudick, 2009: 2; Wątroba, 2017: 81-82). Działania te wynikały z ich wysokiej świadomości politycznej, skutkując aktywnym uczestnictwem we wszelkiego rodzaju ruchach społecznych i politycznych, co uznawali i nadal uznają za jeden z najważniejszych elementów ich systemu wartości (Goldsmith, 2008: 13; Wątroba, 2017: 89), obok możliwości samorealizacji i swobody w wyrażaniu własnej osobowości (Wątroba, 2017: 90).

Boomersi kwestionowali lub redefiniowali tradycyjne systemy wartości, uznając to wręcz za swoje posłannictwo historyczne, a jednocześnie za historyczny przywilej. Generacja ta w największym stopniu ulegała powszechnie nasilającej się laicyzacji, szczególnie w wymiarze behawioralnym. Ich praktyki religijne znacząco różniły się od niemal niezmiennych od stuleci praktyk starszych pokoleń. Nie byli skłonni akceptować arbitralnych - ich zdaniem - sposobów interpretacji rzeczywistości, przyjętych przez główne dla społeczeństw kapitalistycznych nurty religijne, kontestując oferowane przez nie wartości. W innych systemach religijnych - starych czy tworzonych na poczekaniu - poszukiwali wyjaśnień swojej egzystencji, często implementując obce dotąd kulturze zachodniej wartości (Roof, 1993). Zaczęli masowo odrzucać tradycyjne, chrześcijańskie i judaistyczne autorytety duchowe, a część z nich zastępowali nowymi przywódcami duchowymi buddyzmu, hinduizmu czy różnego rodzaju sekt. Tradycyjne religie zaczęli traktować instrumentalnie - jedynie jako zbiór reguł i praktyk zbiorowych. Nie znajdowali w nich, jakże ważnych dla siebie jako osób ciągle dążących do samorealizacji, aspektów duchowych, próbując je odnaleźć w różnych odmianach spirytualizmu, gdzie mogli nawiązać bliższe związki emocjonalne z innymi jednostkami, mieli nadzieję na przeżywanie głębszych doznań, chcieli odszukać wzniosłe uczucia. Studia uniwersyteckie, lektura popularnych wówczas książek, demaskujących tradycyjne wierzenia, pozwoliły im dostrzec ich relatywizm, natomiast ich przywiązanie do idei liberalnych rodziło przekonanie o tym, że to jednostka powinna decydować o wyborze religii i praktyk z nią związanych, a nie presja tradycyjnych instytucji społecznych, w których okowach dotąd funkcjonowali. Fascynacja religiami Wschodu wzięła się u nich z przekonania, że są one bardziej uduchowione niż chrześcijaństwo czy judaizm, sprzyjają indywidualizmowi, są znacznie mniej restrykcyjne. $\mathrm{Z}$ tych ostatnich powodów islam był dla nich kompletnie nieatrakcyjny. Jednakże - wszak czuli się kompletnie niezawiśli w swoich decyzjach - nie 
przyjmowali tych religii w pełni, zarówno w warstwie ideologicznej, jak i obrzędowej, łącząc jedynie dość swobodnie wybrane przez siebie elementy czy symbole, często oderwane od ich właściwych kontekstów, konstruując własne, prywatne mikroreligie. Instytucje religijne zaczęły stanowić odtąd jeden z najważniejszych - obok tradycyjnego modelu rodziny - cel kontestowania tradycyjnego porządku społecznego, gdyż uznali, że w największym stopniu ograniczają one indywidualizm i wolność wyboru jednostki, które były dla nich wartością naczelną. Nie przeszkadzało im to jednak nadal uczestniczyć w obrzędach chrześcijańskich i judaistycznych, szczególnie tych, które są wykorzystywane przez ponowoczesną kulturę konsumpcyjną, chociaż osoby w pełni praktykujące uznają za fanatyków religijnych (Salamone, 2010: 107; Wątroba, 2017: 92-93).

Boomersi uchodzą za idealistów, czasami wręcz niepoprawnych, jednak charakteryzuje ich pragmatyzm i wysoko cenią sobie wartości materialne. Nie ma w tym żadnej sprzeczności, gdyż ów idealizm w odniesieniu do życia codziennego wyraża się w wierze w tzw. mit kalifornijski (Twenge, 2006: 50-51), stymulujący nasyconą hedonizmem i materialistycznym podejściem do życia konsumpcję drugiej połowy XX wieku, a także w wierze we własne możliwości, że ów mit można zrealizować ciężką pracą popartą talentem, że można wieść życie we względnym luksusie.

Mimo iż boomersom zarzuca się odejście od głoszonych w młodości ideałów w stronę samospełnienia w wymiarze ekonomicznym, nadal obcowanie z kulturą, nie tylko popularną, ale i wysoką, stanowi dla nich istotną wartość, decydując - w wymiarze ekonomicznym i kulturowym - o ponowoczesnych wzorcach kultury konsumpcyjnej, a tym samym, w największym stopniu, o stanie rzeczy współczesnego świata. Nadal stanowią najpotężniejszą grupę konsumencką, głównie dzięki swojej zamożności i niegasnącej woli podążania za trendami mody (Wątroba, 2017: 81). Zaczynają jednak uświadamiać sobie z niechęcią, że muszą ustąpić pola młodszym generacjom, że już przekroczyli szczyt swoich możliwości zawodowych i finansowych. Dlatego też coraz bardziej zaczynają cenić upływający czas. Pragnąc go jak najlepiej wykorzystać, nawet kosztem zdrowia, starają się zrealizować odłożone niegdyś plany czy - przynajmniej w części - spełnić niegdysiejsze marzenia, często nabywając dobra czy usługi konsumpcyjne, kierując się nostalgią i nie zważając na to, czy to im wypada (Lancaster, Stillman, 2002: 83-84; Wątroba, 2017: 109).

Chociaż zaawansowani wiekowo boomersi bywają oskarżani o zastąpienie idealizmu materializmem, kontestację konformizmem i pogoń, w życiu dorosłym, za sukcesem finansowym, to jednak nie można odbierać im zasług w dążeniu do trwałego upodmiotowienia jednostki oraz do radykalnego ograniczenia wszelkiego rodzaju dyskryminacji (może poza osobami o odmiennych od nich poglądach), a także w krytyce - czasami nasyconej pozytywnym cynizmem - kierowanej pod adresem mianowanych i pochodzących z wyboru decydentów. Za ich 
najważniejsze dokonanie należy uznać wykreowanie i upowszechnienie szeroko rozumianej popkultury, której najbardziej spektakularnym wymiarem stała się muzyka rock'n'rollowa (Lancaster, Stillman, 2002: vi; Wątroba, 2017: 106).

Reasumując, można uznać, na wysokim poziomie uogólnienia, że boomersi przyjęli system wartości kwestionujący tradycję, którego zasadnicze elementy to: tolerancja dla odmienności, podmiotowość jednostek, emancypacja kobiet, pluralizm myśli i wyznań oraz autoekspresja. Narzędziami implementacji tego systemu wartości były: telewizja, muzyka rockowa czy skomercjalizowana kultura, a przede wszystkim skomodyfikowana subkultura młodzieżowa lat sześćdziesiątych (Wątroba, 2017: 129). I nawet jeśli istotna część z nich, co potwierdzają obecnie u progu zaawansowanej starości, w skrytości podzielała - w pewnej mierze - wartości tradycjonalistów, to nie są już w stanie zmienić swojego wizerunku sprawców kontrkulturowej rebelii (Adams, 2010: 11-12; Wątroba, 2017: 115).

\section{Pokolenie X}

Pokoleniu temu, podobnie jak cichemu pokoleniu, przyszło żyć w cieniu wielkiej, żywotnej i ekspansywnej generacji, jaką byli boomersi. Tak jak pokolenie żyjące w cieniu najwspanialszego pokolenia byli zmuszeni obrać strategię wykluczającą otwartą konfrontację ze starszą kohortą, strategię nacechowaną pragmatyzmem, stąd też ich system wartości wykluczał popularny wśród boomersów idealizm. Podobnie, a nawet bardziej niż starsza generacja kwestionowali tradycyjne instytucje społeczne, jednak nie z pobudek idealistycznych, lecz wskutek własnych doświadczeń z okresu dojrzewania, kiedy to ulegały one zaawansowanej erozji w obliczu rewolty kulturowej. Odrzucanie boomerowskiego idealizmu popchnęło ich również do eksperymentowania z odmiennymi od tradycyjnych wierzeniami, skutkując jednak fatalizmem, okultyzmem czy zainteresowaniem parapsychologią, a nie fascynacją religiami Wschodu. Boomerowski indywidualizm i stadny imperatyw samorealizacji zastąpili zaś niezależnością i dążeniem do samowystarczalności (Wątroba, 2017: 272).

Negatywna percepcja instytucji społecznych, poparta tak wyraźnie charakteryzującym pokolenie X sceptycyzmem, zrodziła w jego przedstawicielach przekonanie, że należy polegać tylko na samym sobie, ewentualnie na wąskim gronie zaufanych przyjaciół, natomiast nie należy oddawać swojego losu w ręce instytucji społecznych. Niemal wszędzie dostrzegają oni zagrożenia, co budzi w ich permanentną nieufność, szczególnie wobec odmienności i różnorodności. Dlatego ważną wartością jest dla nich szeroko rozumiane bezpieczeństwo własne i bliskich (Wątroba, 2017: 280). Diametralnie różnią się w tym aspekcie od odważnych do granic nieroztropności boomersów. 
Nieufność wobec instytucji społecznych, tradycyjnych systemów wartości i dotychczasowych - a w zasadzie wszelkich - autorytetów, w szczególności w stosunku do rodziny, szkoły, uniwersytetu, religii, armii, korporacji czy przywództwa politycznego, sprawiła, że nierzadko kojarzą je z korupcją, krzywoprzysięstwem, kłamstwem, obłudą, defraudacją czy innymi działaniami kryminogennymi. Pokolenie X stanowi pierwszą generację, która wątpi w trwałość instytucjonalnych czy wręcz międzyludzkich więzów, która wierzy jedynie w siebie jako skuteczny podmiot sprawczy (Lancaster, Stillman, 2002: 25). Z tego też powodu przedstawiciele tego pokolenia unikają zorganizowanych działań społecznych, uznając je za krępującą opresję, manipulację ze strony polityków, którzy ich zdaniem przestali już udawać, że kierują się jakimiś zasadami (Rosen, 2001: 72). Jego przedstawiciele jako najbardziej właściwą strategię w takiej rzeczywistości obierają zazwyczaj kameleonizm, ułatwiający osobistą promocję, pomocny w radzeniu sobie ze stresem w sytuacjach kryzysowych czy chroniący przed degradacją zawodową i społeczną. Zarzucając innym brak szczerości, sami starają się wieść żywot kameleona, dopasowując się do zmiennej sytuacji i jednocześnie pilnując, aby zanadto nie angażować się w trwalsze relacje (Rosen, 2001: 30; Wątroba, 2017: 140).

Od starszych generacji różni ich także filozofia życia, wynikająca z poczucia pokrzywdzenia - w ich przekonaniu - przez historię: chodzi tu o niższą liczebność, a co za tym idzie - słabszą siłę przebicia w obliczu licznych boomersów, załamanie się koniunktury, kryzys energetyczny, a także nasilającą się relatywizację dotychczas obowiązujących systemów wartości i autorytetów. Dlatego też obrali strategię przetrwania opartą na egoistycznym, pragmatycznym, realistycznym zabieganiu jedynie o siebie i własne sprawy (Wątroba, 2017: 273).

Oprócz wspomnianych już niezależności i osobistej wolności wysoko cenią sobie kompetencje, osiągnięcia zawodowe i życiowe, profesjonalizm, a także wysoki status, głównie ekonomiczny. Kariera zawodowa ma dla nich duże znaczenie, ale jest nie mniej ważna niż życie rodzinne i w tej materii różnią się od boomersów (Ryan, 2007: 16; Wątroba, 2017: 137).

Pokolenie X jest uważane za pierwszą postchrześcijańską generację, gdyż bardziej interesuje je aspekt duchowy (spirituality) religii niż instytucjonalny. Nie poszukują Boga w świątyniach. Kontestują tradycyjną rolę instytucji Kościoła, skupiając się na naturalnych relacjach z ludźmi, a nie na samoograniczaniu się. Religia jest dla tej generacji raczej makrowartością, a nie kompletnym, niezależnym wymiarem życia (Johnstone, 2013: xiii, xv, 23-24). Praktyki religijne traktują raczej instrumentalnie, ograniczając się do sfery rytualnej, szczególnie do tych jej form, które uległy ponowoczesnej komodyfikacji (Wątroba, 2017: 140-141).

Reasumując, świadomość społeczną, a co za tym idzie - system wartości przedstawicieli pokolenia X kształtowała samodzielność jego przedstawicieli, będąca konsekwencją dorastania w samotności, bez rodzeństwa, nieustannie pracujących rodziców, mieszkających osobno dziadków, co zrodziło u nich poczucie nie- 
ufności, sceptycyzmu wobec głębszych relacji z innymi i tradycyjnych instytucji, głównie rodziny. Nie mniej istotny wpływ na ich system wartości miało świetne wykształcenie, w dużej mierze na poziomie uniwersyteckim. Jako pierwsze pokolenie w pełni korzystali z liberalnego klimatu uniwersytetów, które stały się pierwszoplanową, kulturotwórczą instytucją ponowoczesnego świata $-\mathrm{z}$ jednej strony azylem dla wysokiej kultury, a z drugiej stymulatorem wartościowych trendów kultury popularnej. $Z$ czasem jednak pojawiło się u nich rozczarowanie, wynikające $\mathrm{z}$ rozdźwięku między treściami programów akademickich czy liberalnych programów politycznych a konkretnymi działaniami podmiotów je głoszących (Wątroba, 2017: 155). Kolejne generacje kształtują swoją tożsamość w warunkach daleko idącego rozszczepienia źródeł/podmiotów proponujących szerokie spektrum znacząco zrelatywizowanych systemów wartości.

\section{Pokolenie echo boomersów}

Podobnie jak w przypadku baby boomers nazwa tej generacji początkowo wiązała się ze znacznym wzrostem liczby urodzeń w latach osiemdziesiątych, co było naturalną konsekwencją zakładania rodzin przez jakże liczną generację urodzonych w pierwszych powojennych dekadach. Jako jej demograficzne echo nowe pokolenie stało się najbardziej liczną generacją w historii (Tapscott, 2009: 11-13). Jednak tego terminu nie należy rezerwować dla niego jedynie dlatego, że stanowi potomstwo baby boomers, gdyż zaliczamy do niego także dzieci wielu przedstawicieli pokolenia X (Sujansky, Ferri-Reed, 2009: 58-59). To nie obiektywne przesłanki demograficzne sprawiają, że takie określenie wydaje się najbardziej zasadne dla nowego pokolenia. Podobnie było w przypadku boomersów. Termin echo boomersi należy przede wszystkim interpretować w kategoriach podobieństw charakterystyki i tożsamości pokoleniowej obu generacji (szerzej w: Wątroba, 2017: 159-162).

Przedstawiciele pokolenia echo boomers, podobnie jak boomersi, są uważani za jednostki silnie zorientowane na siebie, samolubne. Zarzuca się im także narcyzm. Również dążą do samorealizacji, jednak cechuje ich bardziej widoczna niż u boomersów umiejętność wyrażania uczuć. Dzięki nowym technologiom i technikom komunikacji nieustannie wysyłają w świat sygnały o emocjach związanych z pracą czy spędzaniem czasu wolnego, a także z relacjami ze znajomymi i bliskimi im osobami. W dążeniu do samoaktualizacji, podobnie jak boomersi, ciągle się kształcą, uczą języków obcych, podróżują w celach poznawczych. Są równie, a nawet bardziej otwarci na inność i wrażliwi na ludzką krzywdę, często podejmują działania filantropijne. Aktywnie działają na rzecz otoczenia, wykazują szczególną dbałość o środowisko naturalne (Ryan, 2007: 18). Wzorowana na starszym pokoleniu zaradność pozwala im odnaleźć się w różnych sytuacjach. Wielu z nich, wkraczając w wiek nastoletni, potrafi wyjątkowo dojrzale realizować swoje za- 
mierzenia, niejednokrotnie wykazując się nową, legalną formą sprytu ulicznego (Sheahan, 2005: 7).

Echo boomersów cechuje swoisty, optymistyczny sceptycyzm czy raczej twórcza nieufność, rodzaj dociekliwości stymulującej dążenie do nowych, ich zdaniem lepszych rozwiązań. Nie kwestionują tak radykalnie jak baby boomers instytucji społecznych, a wręcz próbują je rewitalizować - nawet te, które są osadzone w tradycji dziewiętnastowiecznej (Wątroba, 2017: 280). Ich, tak typowy dla starszych boomersów, optymizm ma podobne źródła - obie generacje były rozpieszczane przez rodziców i dziadków, tyle że w przypadku młodszych miało to miejsce na znacznie wyższym poziomie rozwoju cywilizacyjnego i ekonomicznego. Nadopiekuńczość starszych generacji wobec boomersów została spotęgowana ponowoczesnym permisywizmem, jakiego doświadczyli echo boomersi, a doskonała, niemal nieustannie rosnąca od kilku dekad koniunktura, idąca w parze z rozpasaną, ponowoczesną, symboliczną konsumpcją, wyniosła ich optymizm dotyczący przyszłości na niespotykany poziom, zacznie przewyższający ten, który cechował najbardziej dotąd optymistyczną generację złotych boomersów (Wątroba, 2017: 273).

Mimo iż pokolenie echo boomers posiada wiele cech, postaw i wartości charakterystycznych dla pierwszych boomersów, stara się budować własny systemy wartości i przekonań, oparty na selekcji bardzo dobrze poznanych praktyk duchowych i społecznych, często bardzo odległych historycznie i przestrzennie od ich obecnego środowiska kulturowego (Tulgan, 2009: 9-10; Wątroba, 2017: 183). I chociaż starsze generacje zarzucają im, że są nieoduczeni, że nie znają historii, to jednak - ku ich zaskoczeniu - są znacznie lepiej wykształceni w tym zakresie niż poprzednie pokolenia, dzięki szerszemu dostępowi do wiedzy, głównie za sprawą nowych technologii informacyjnych, ale także dzięki eksploracji historii przez ponowoczesną kulturę popularną.

Pokolenie to, podobnie jak baby boomers, wysoko ceni sobie pracę zespołową, wykazując silny instynkt sukcesu grupowego oraz silne więzi rówieśnicze. Jego przedstawiciele różnią się jednak od swoich poprzedników znacznie niższym poziomem lojalności wobec współpracowników, przełożonych czy pracodawców. Właściwie w ostatnich dwóch przypadkach trudno od nich jej oczekiwać. Pragną swobody we wszystkich działaniach, głównie wolności ekspresji, którą - ich zdaniem - zapewnia internet. W swojej ekspresji próbują dostosowywać wszystko do własnych potrzeb i wszystko, co robią, starają się personalizować. W pracy i edukacji czy życiu towarzyskim szukają przyjemności, w czym nie różnią się od trzech wcześniejszych generacji, chociaż mniejsze znaczenie ma dla nich status ekonomiczny - może dlatego, że w większości nie doświadczyli biedy ${ }^{2}$. W przeciwieństwie do starszych pokoleń odrzucają rozdzielność tych sfer aktywności,

2 Niniejsza analiza, a co za tym idzie - powyższe uogólnienie, dotyczy wysoko rozwiniętych państw kapitalistycznych. 
łącząc pracę z nauką i zabawą. Wszędzie wykazują tak charakterystyczną dla nich permanentną interaktywność i głęboką potrzebę szybkiego działania, szybkiej komunikacji z innymi czy szybkiego pozyskiwania niezbędnych informacji, porad i ekspertyz, zawsze oczekując błyskawicznej odpowiedzi czy odzewu. Mają wręcz obsesję innowacyjności, a ponieważ ich dorastanie znaczyła ciągła implementacja nowych rozwiązań technicznych i technologicznych, stali się orędownikami tak charakterystycznego dla ponowoczesności imperatywu nieustannego zmieniania wszelkich rozwiązań determinujących rzeczywistość, bez względu na to, czy te nowe są lepsze od wypieranych przez nie (Tapscott, 2009: 34-36; Wątroba, 2017: 165-166).

Reasumując, pokolenia echo boomers nie należy traktować jako kopii generacji baby boomers, a w zasadzie generacji złotych baby boomers. Mimo znaczących podobieństw w portrecie socjologicznym obu pokoleń wyraźnie widać różnice między nimi. Nie są to jednak różnice kluczowe, które mogłyby sfalsyfikować zasadność stosowania terminu echo boomers, znacznie bardziej adekwatnego niż inne, przeżywające swoje okresy popularności i zapomnienia (Wątroba, 2017: 157-163). Bardzo ważnym podobieństwem obu pokoleń boomersów jest niezwykle wyraźne - w wielu wymiarach egzystencji młodszej generacji - zjawisko wzmacniania charakterystycznych cech pokolenia złotych boomersów, które należałoby określić terminem rezonansu pokoleniowego (Wątroba, 2017: 30, 169, 270, 283, 298, 322).

\section{Milenialsi (millennials) czy raczej pokolenie internetu}

Z socjologicznego punktu widzenia trudno konstruować portret pokolenia zaledwie wkraczającego - w przypadku najstarszych jego reprezentantów - w dorosłość. Tym bardziej że proces jego dorastania ma miejsce w okresie niskiej dynamiki zmian społecznych, która nie sprzyja ujawnianiu się wyrazistości pokoleniowej. Żadna $z$ analizowanych tutaj generacji nie zasłużyła sobie na adekwatne, powszechnie uznane określenie w tak młodym wieku. Póki co należy przyjąć terminy robocze, przy założeniu niskiego prawdopodobieństwa, że zostaną one utrzymane w przyszłości. Wielce wątpliwym terminem są milenialsi (z powodu w pewnym stopniu absurdalnych podstaw etymologicznych), a i pokolenie internetu także ma wąłe podstawy, przy założeniu dalszego rozwoju tego medium ${ }^{3}$. Jedynie w przypadku jego technologicznej czy raczej polityczno-ekonomicznej

3 Wynalazek samochodu, nie mniej epokowy, nie znalazł żadnego odzwierciedlenia w określaniu jakiejkolwiek generacji pokoleniem motoryzacji. 
zagłady generacja ta może być przez historyków społecznych z nim łączona, przy braku innych podstaw pokoleniowej wyrazistości, które mogą pojawić się na dalszych etapach jej życia. Dlatego też jedynym uprawnionym metodologicznie zabiegiem pozostaje zdiagnozowanie różnic $\mathrm{w}$ stosunku do generacji wcześniejszej - wskazanie symptomów pokoleniowych transgresji.

O ile poprzednia generacja najbardziej przypomina złotych boomersów, o tyle przedstawiciele milenialsów/pokolenia internetu zdają się wykazywać podobieństwa do najwspanialszego pokolenia, czyli do swoich dziadków i pradziadków. Są one widoczne w stosunku do wartości rodzinnych, aktywizmu społecznego i politycznego oraz optymizmu dotyczącego możliwości rozwiązywania problemów społecznych (Winograd, Hais, 2008: 67-68). Milenialsi/pokolenie internetu z wielkim szacunkiem odnosi się do dokonań swoich dziadków i pradziadków, do odwagi w podejmowaniu ambitnych wzywań, realizacji wielkich projektów, kultywowania tradycyjnej kultury opartej na silnych więzach rodzinnych i przyjacielskich, a przede wszystkim do przyjęcia na siebie odpowiedzialności w trudnych dla ludzkości momentach (Howe, Strauss, 2000: 334-335.).

$\mathrm{Z}$ najwspanialszym pokoleniem milenialsów/pokolenie internetu łączy także optymizm, wiara w skuteczność działań zbiorowych czy postawa proobywatelska i zaangażowanie polityczne. Podzielają wiarę swoich dziadków w demokrację jako potencjalną siłę sprawczą naprawy świata. W naśladowaniu swoich dziadków odnajdują możliwość poprawienia tego, co zepsuli - ich zdaniem - baby boomers. Uważają, że pokolenie dziadków dokonało wielkich rzeczy, jednocząc jednostki w silną wspólnotę (Strauss, Howe, Markiewicz, 2006: 49; Tapscott, 2009: 6; Wątroba, 2017: 174-175, 180).

Milenialsi różnią się jednak zasadniczo od wszystkich generacji - może z wyjątkiem części echo boomersów - jeśli idzie o chęć usamodzielnienia się ekonomicznego i społecznego. I nie należy tego tłumaczyć trudnościami w znalezieniu pracy czy niebotycznie wysokimi cenami nieruchomości, a nierzadko znaczącym obciążeniem kredytowym na pokrycie kosztów studiów. Są to jedynie obiektywne uwarunkowania. Ważniejsze wydają się przyczyny subiektywne, wynikające z ich warunków dorastania pod opiekuńczym parasolem rodziców i dziadków, skutkujące silnym przywiązaniem emocjonalnym, a także hedonistycznym podejściem do życia oraz niską skłonnością do wyrzeczeń i chęci kierowania własnym losem. Jednak w sytuacji, gdy taka forma egzystencji, na cudzy rachunek, na dłuższą metę okaże się niemożliwa, mogą popaść w apatię bądź defetyzm. Mogą również zakwestionować instytucje, na czele których stoją obecnie starsze pokolenia, co może grozić kolejnym - po pół wieku - zderzeniem pokoleń ( $g e$ neration clash). Do tego potrzebują sojuszników, najlepiej echo boomersów, którzy jednak mogą mieć zbyt wiele do stracenia w radykalnym konflikcie pokoleń, pozostawiając $\mathrm{w}$ cieniu koncyliacyjne czy raczej konformistyczne pokolenie $\mathrm{X}$, przejmując ster historii bezpośrednio od baby boomers. Trudno także wskazać 
na jakieś przesłanki, które upoważniałyby do stwierdzenia, iż przedstawiciele milenialsów/pokolenia internetu są zdolni do samodzielnego konstruowania swojej przyszłości, chociaż stanowią „,falę młodości, która ma do tego pełne prawo, ma rosnące aspiracje, $i$ jest w pełni świadoma swoich możliwości, oraz rodzących się oczekiwań, które sięgają wysoko" (Tapscott, 2009: 310; Wątroba, 2017: 199). Jest na to za wcześnie i być może swoich ideowych przywódców odnajdą wśród doskonale wykształconych, lecz niezadowolonych ze swojego losu przedstawicieli mniejszościowej grupy pokolenia echo boomersów, nieakceptującej większościowej wizji jego egzystencji - jak niegdyś baby boomers znaleźli takich wśród nielicznych szczęśliwców z cichego pokolenia.

\section{Podsumowanie}

Próbując dokonać podsumowania niniejszej analizy w syntetycznej formie, należy wskazać na kluczowe dla każdej z omawianych generacji wartości czy raczej na to, co jest w ich życiu ważne. W zawartej w Tabeli 1 syntezie pogrupowano - zgodnie z powszechnie stosowaną, chociaż kwestionowaną przez autora, konwencją - najwspanialsze pokolenie i ciche pokolenie w tradycjonalistów, a złotych boomersów i pokolenie Jones w baby boomers. Zabieg taki ma swoje uzasadnienie w tym, iż obie pary generacji charakteryzuje homogeniczność ich świadomości społecznej, a co za tym idzie - systemów wartości, z kolei wyraźną heterogeniczność dostrzegamy w percepcji historii, w jej pokoleniowym doświadczaniu oraz w roli tych pokoleń.

Tabela 1. Kluczowe wartości dorosłych generacji w ponowoczesnym kapitalizmie

\begin{tabular}{|c|c|}
\hline $\begin{array}{l}\text { Tradycjonaliści: } \\
\text { najwspanialsze } \\
\text { pokolenie }+ \text { ciche } \\
\text { pokolenie }\end{array}$ & $\begin{array}{l}\text { - Odpowiedzialność } \\
\text { - Lojalność } \\
\text { - Instytucje społeczne (rodzina, Kościół, władza polityczna) } \\
\text { - Wiara w oświeceniowy projekt } \\
\text { - Praca zespołowa (oddanie, podporządkowanie się, rezygnacja } \\
\text { z partykularnych celów) } \\
\text { - Poświęcenie się dla młodszych pokoleń }\end{array}$ \\
\hline $\begin{array}{l}\text { Baby boomers: złoci } \\
\text { boomersi + pokolenie } \\
\text { Jones }\end{array}$ & $\begin{array}{l}\text { - Samorealizacja } \\
\text { - Egocentryzm (poczucie historycznego uprzywilejowania) } \\
\text { - Wiedza } \\
\text { - Optymizm (wiara w to, że wszystko jest możliwe, że postęp jest } \\
\text { nieograniczony) } \\
\text { - Bezgraniczna wiara w projekt oświeceniowy } \\
\text { - Wola rywalizacji (także w zespołach) } \\
\text { - Ego kalifornijskie (przyjemności, głębsze doznania, potrzeba } \\
\text { uznania) } \\
\text { - Kult wiecznej młodości }\end{array}$ \\
\hline
\end{tabular}




\begin{tabular}{|c|c|}
\hline $\begin{array}{l}\text { Baby boomers: złoci } \\
\text { boomersi + pokolenie } \\
\text { Jones }\end{array}$ & $\begin{array}{l}\text { - Wolność i swoboda zachowań, upodmiotowienie jednostki } \\
\text { - Konsumpcjonizm (konsumować to znaczy w pełni żyć) } \\
\text { - Kariera zawodowa (nawet kosztem rodziny) } \\
\text { - Zaangażowanie polityczne } \\
\text { - Permanentna aktywność (także na starość) }\end{array}$ \\
\hline Pokolenie X & $\begin{array}{l}\text { - Sceptycyzm (zwątpienie w oświeceniowe ideały) } \\
\text { - Pragmatyzm } \\
\text { - Skupienie się na sobie (w poczuciu zagrożenia) } \\
\text { - Etyka samospełnienia wyniesiona na wyższy poziom indywidualizmu } \\
\text { - Docenianie komfortu } \\
\text { - Uleganie gadżetyzacji konsumpcji } \\
\text { - Zachowawczość w nakreślaniu celów życiowych } \\
\text { - Lojalność jedynie wobec najbliższych przyjaciół } \\
\text { - Profesjonalizm } \\
\text { - Apolityczność } \\
\text { - Uznawanie egalitaryzmu za hipokryzję }\end{array}$ \\
\hline Echo boomersi & $\begin{array}{l}\text { - Samorealizacja } \\
\text { - Egocentryzm } \\
\text { - Optymizm (psychologistyczny) } \\
\text { - Wola konkurowania (ale bez determinacji) } \\
\text { - Ego kalifornijskie (potrzeba uznania) } \\
\text { - Profesjonalizm } \\
\text { - Kariera korporacyjna } \\
\text { - Połączenie pracy i czasu wolnego } \\
\text { - Umiarkowane zaangażowanie polityczne }\end{array}$ \\
\hline $\begin{array}{l}\text { Milenialsi/pokolenie } \\
\text { internetu }\end{array}$ & $\begin{array}{l}\text { - Realizm } \\
\text { - Relatywizm } \\
\text { - Prezentyzm } \\
\text { - Samozatrudnienie } \\
\text { - Prosumpcja } \\
\text { - Asertywność komunikacyjna } \\
\text { - Usieciowienie (bezrefleksyjne) } \\
\text { - Otwartość społeczna } \\
\text { - Zastąpienie autorytetów ekspertami (często pozornymi) }\end{array}$ \\
\hline
\end{tabular}

Źródło: opracowanie własne

\section{Bibliografia}

Adams M. (2010), Styin' Alive How Canadian Baby Boomers Will Work, Play, and Find Meaning in the Second Half of Their Adult Lives, Viking Canada, Toronto.

Benckendorff P., Moscardo G., Pendergast D. (2010), Introduction, [w:] Benckendorff P., Moscardo G., Pendergast D. (red.), Tourism and Generation Y, CAB International, Cambridge, s. $\mathrm{x}$-xii.

Brokaw T. (2001), The Greatest Generation, Dell Publishing, New York.

Carlson E. (2008), The Lucky Few. Between the Greatest Generation and the Baby Boomers, Springer, Dordrecht-London.

Cochran L.J., Rothschadl A.M., Rudick J.L. (2009), Leisure Programming for Baby Boomers, Human Kinetics, Champaign. 
Daniels R. V. (2006), The Fourth Revolution. Transformations in American Society from the Sixties to the Present, Routledge, New York.

Eisenstadt S. N. (2003), From Generation to Generation, Transaction Publishers, New Brunswick.

Erickson T. (2008), Plugged In. The Generation Y Guide to Thriving at Work, Harvard Business Review Press, Cambridge.

Fatyga B., Pokolenie, [w:] J. Bokszański (red.), Encyklopedia socjologii. Suplement, Wydawnictwo Naukowe PWN, Warszawa 2005, s. 193-197.

Garewicz J. (1983), Pokolenie jako kategoria socjofilozoficzna, „Studia Socjologiczne”, nr 1, s. $75-87$.

Gillon S. M. (2004), Boomer Nation. The Largest and Richest Generation Ever, and How It Changed America, Free Press, New York.

Goldsmith J. (2008), The Long Baby Boom. An Optimistic Vision for a Graying Generation, Johns Hopkins University Press, Baltimore.

Howe N., Strauss W. (1991), Generations. The History of America's Future, 1584 to 2069, William Morrow and Company, New York.

Howe N., Strauss W. (2000), Millennials Rising. The Next Great Generation, Vintage Books, New York.

Johnstone C. (2013), Embedded Faith. The Faith Journeys of Young Adults within Church Communities, Wipf \& Stock, Eugene.

Krauss Whitbourne S., Willis S.L. (2006), The Baby Boomers Grow Up. Contemporary Perspectives on Midlife, Psychology Press, Hove.

Lancaster L.C., Stillman D. (2002), When Generations Collide. Traditionalists, Baby Boomers, Generation X-ers, Millennials: who They are?, Harper Business, New York.

Mannheim K. (1952), The Problem of Generations, [w:] P. Kecskemeti (red.), Essays on the Sociology of Knowledge by Karl Mannheim, Routledge \& Kegan Paul, New York, s. 276-322.

Mentré F. (1920), Les Générations Sociale, Bossard, Paris.

Morgan L.A., Kunkel S.R. (2011), Aging, Society, and the Life Course, Springer, New York.

Owram D. (1997), Born at the Right Time. A History of the Baby Boom Generation, University of Toronto Press, Toronto.

Pendergast D. (2010), Getting to Know Y Generation, [w:] P. Benckendorff, G. Moscardo, D. Pendergast (red.), Tourism and Generation Y, CAB International, Cambridge, s. 1-15.

Roof W.C. (1993), A Generation of Seekers. The Spiritual Journeys of the Baby Boom Generation, Harper, San Francisco.

Rosen B.C. (2001), Masks and Mirrors. Generation X and the Chameleon Personality, Praeger, Westport.

Ryan R. (2007), Live First, Work Second. Getting Inside the Head of the Next Generation, Next Generation Consulting, Madison.

Salamone F. A. (2010), Religion and the Baby Boomers, [w:] R. Monhollon (red.), Baby Boom. People and Perspectives, ABC-CLIO, Santa Barbara, s. 105-116.

Savage J. (2008), Teenage. The Prehistory of Youth Culture, Penguin, New York.

Sheahan P. (2005), Generation Y. Thriving and Surviving With Generation Y at Work, Hardie Grant, Melbourne.

Starr K. (2009), Golden Dreams. California in an Age of Abundance 1950-1963, Oxford University Press, Oxford-New York.

Strauss W., Howe N., Markiewicz P. (2006), Millennials and the Pop Culture. Strategies For a New Generation of Consumer in Music, Movies, Television, the Internet, and Video Games, LifeCourse Associates, Great Falls.

Sujansky J.G., Ferri-Reed J. (2009), Keeping the Millennials. Why Companies Are Losing Billions in Turnover to This Generation, and What to Do About..., John Wiley \& Sons, Hoboken. 
Świda-Ziemba H. (1995), Wartości egzystencjalne młodzieży lat dziewięćdziesiątych, Wydawnictwo Uniwersytetu Warszawskiego, Warszawa.

Tapscott D. (2009), Grown Up Digital. How the Net Generation is Changing Your World, McGraw-Hill, New York.

Tulgan B. (2009), Not Everyone Gets a Trophy. How to Manage Generation Y, Jossey-Bass, San Francisco.

Twenge J.M. (2006), Generation Me. Why Today's Young Americans Are More Confident, Assertive, Entitled, and More Miserable Than Ever Before, Free Press, New York.

Wątroba W. (2012), Baby Boomers a obecny kryzys finansowy, [w:] S. Partycki (red.), Kryzys finansowy. Przebieg, skutki społeczno-gospodarcze w Europie Środkowej i Wschodniej, t. 2, Wydawnictwo Katolickiego Uniwersytetu Lubelskiego, Lublin, s. 63-73.

Wątroba W. (2017), Transgresje międzypokoleniowe późnego kapitalizmu, Wydawnictwo Uniwersytetu Ekonomicznego we Wrocławiu, Wrocław.

Wątroba W. (2018), Trans-generational regime of late capitalism. Introducing a new sociology of generation, „International Journal of Arts and Science” [w druku].

Winograd M., Hais M.D. (2008), Millennial Makeover. My Space, YouTube, and the Future of American Politics, Rutgers University Press, New Brunswick.

\title{
Transgressivity of Value System of Generations Residing in the Contemporary Capitalism
}

\begin{abstract}
An article has revisited a classical interpretation of category of generation, suggesting strict periodization and equal time periods implementing to the generation residing in the period of so-called late capitalism. The article is based on the methodology of comparative study, stressing a new approach to the sociological perception of generation as an outcome of social and psychological processes, stimulating specific identity and consciousness, different, or being more specific - transgressive, from other generations, denying previous approach based on the similar birthdate. An analysis has focused of the value systems differences of generation inhabiting well-developed capitalistic countries after II World War.
\end{abstract}

Keywords: generation, Silent Generation, Baby Boomers, Generation Jones, Generation X, Echo Boomers, Millennials, Generation Y, Internet Generation

JEL: A13

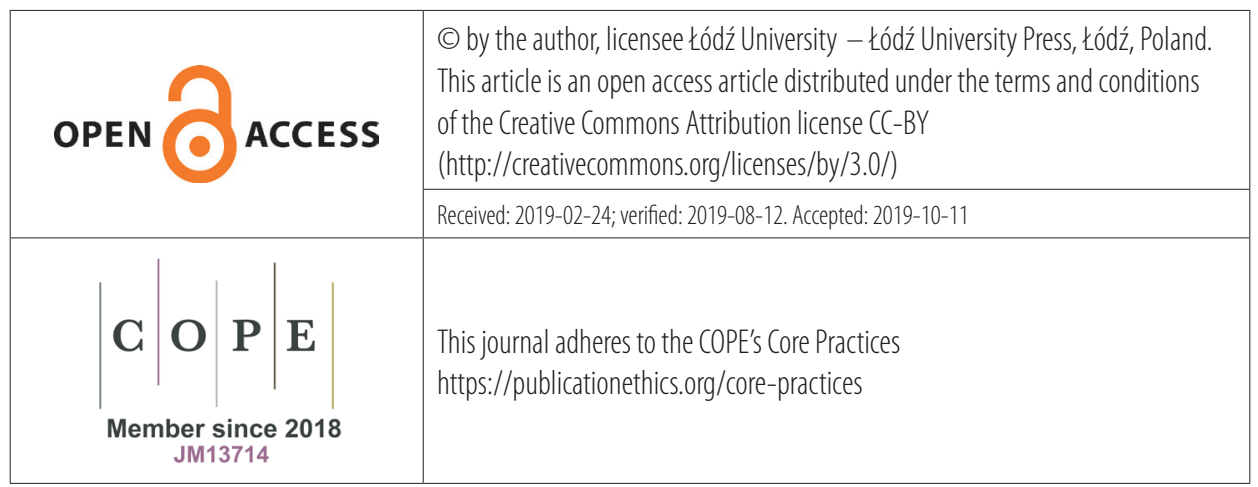

